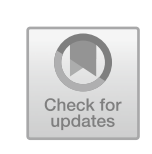

\title{
Certified Insane: Concepts and Practices
}

\section{INTRODUCTION: LILY'S STORY}

Henry $\mathrm{R}$ was concerned about his wife Lily, a 43-year-old mother-oftwo. She had been nursing his stepmother "which was very trying" and it had "unhinged her mind". Mindful of the stressful domestic environment, the family sought no treatment until the situation was desperate. The stigma of certification, the pauper lunatic label, and the belief that the war was nearly over so the stress would diminish, were likely to have contributed to their decision to wait. Lily was admitted to the mental observation ward at St. John's Road workhouse infirmary in Islington in July 1918, and from there to Colney Hatch Asylum. ${ }^{1}$ Mentally disturbed people were frequently admitted first to an observation ward, likely to be relatively close to their home compared to an asylum beyond the suburbs. However, these wards were often ill-equipped and "without means of classification of maniacal, suicidal, or mildly affected patients". ${ }^{2}$ Interactions between staff and patients could be unhelpful: a former asylum patient who had been certified while in an observation ward recalled that the workhouse medical officer was "a gentleman and very kind", but the head attendant was "a complete savage in every way". 3

From observation ward to certification under the Lunacy Act 1890 was a small medico-legal step with profound implications for the patient. Once a person was certified under the Act an asylum was obliged to accept them, regardless of any underlying physical disorder causing their mental

C. Hilton, Civilian Lunatic Asylums During the First World War, Mental Health in Historical Perspective, https://doi.org/10.1007/978-3-030-54871-1_3 
disturbance. The most experienced psychiatrists, those working in the asylum, had no part in deciding who would be admitted under their care. This was inequitable with the authority given to general hospital doctors treating physical conditions, who decided which patients to admit to their wards. The system favoured the opinions of general hospital doctors who did not want to treat disturbed patients, especially if perceived as elderly or likely to have an unfavourable prognosis. As John Keay, president of the Medico-Psychological Association (MPA), commented in 1918: "the most trifling mental abnormality is used as the pretext for sending to the asylum". 4 One neurologist proposed that every general hospital should provide wards to treat mentally disturbed patients who had underlying physical disorders, including isolation wards where quiet was not essential, to ensure that they received the most appropriate treatment. ${ }^{5}$ The existence of such wards is elusive.

Attitudes of senior doctors in general hospitals contributed to increasing the proportion of older people in asylums who were regarded as senile and untreatable. By the time war broke out, over 15 per cent of asylum patients were over 60 years old, drawn from five per cent of the population of the same age group. ${ }^{6}$ Some, such as Emma Matilda L (Fig. 3.1), were admitted "in a dying condition and all [were] in a very reduced bodily condition."7 Asylum staff were perplexed why such physically ill people were sent to their institutions rather than treated in the local general hospital. ${ }^{8}$

Returning to Lily, the obligatory doctor's certificate required for asylum admission recorded her disturbed behaviour:

highly amused with herself; when asked questions she starts quoting some simple rhyme and keeps time to the metre by shaking her head from side to side and ends with an emphatic nod and then glares at you. She is sometimes very noisy and destructive, smashing the mug she is drinking from.

On arrival at Colney Hatch the medical officer examined her and summarised:

She is suffering from mania. Is very noisy, restless and agitated - wanders about the room talking incessantly to herself, and is at times resistive to attention. She has obvious hallucinations, both visual and auditory - hears and answers the voices of imaginary persons, and describes the wonderful 


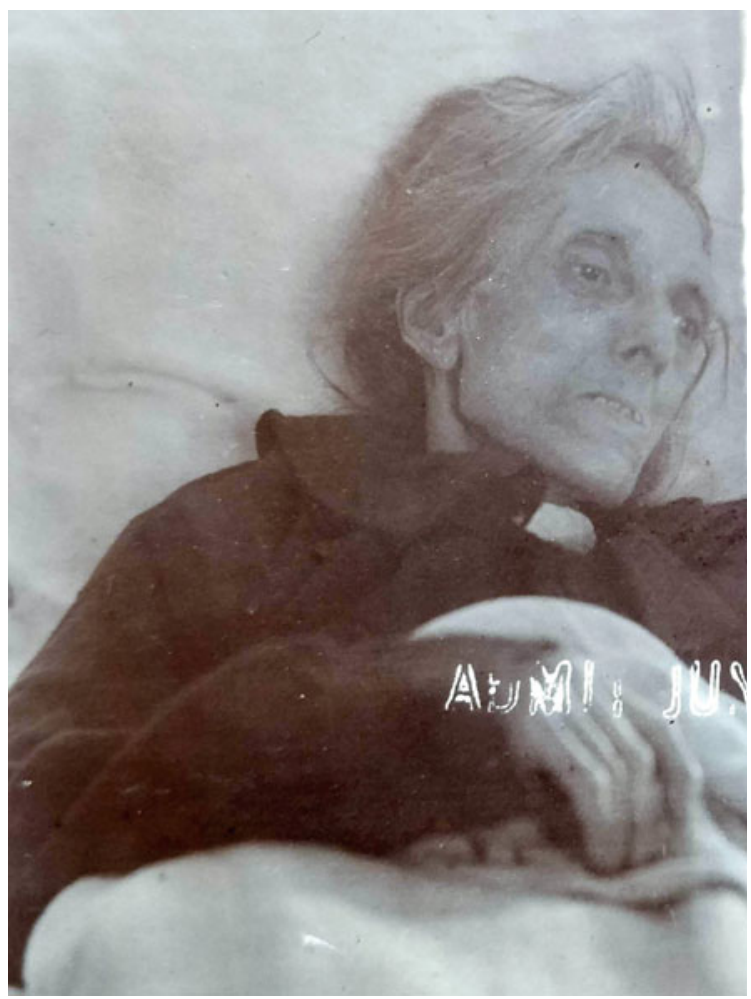

Fig. 3.1 Emma Matilda L, just after admission to an asylum (Photographs of female patients at Colney Hatch 1918-1920 H12/CH/B/18/004 LMA)

coloured lights which appear in the padded room at night and by their movements convey messages to her. She mistakes identities recognising strangers as old friends and is faulty in her personal habits. She is in great impaired health suffering from advanced Pulmonary Tuberculosis and is regarded as not likely to live long. ${ }^{9}$

The term mania indicated a general state of mental and physical overactivity, rather than the specific diagnosis of manic-depression (bipolar disorder). ${ }^{10}$ Lily's mania was probably "acute delirious mania" or "acute delirium", both terms used at the time. ${ }^{11}$ It was often rapidly fatal because it was associated with underlying severe physical illness, a relationship 
recognised since antiquity. ${ }^{12}$ The workhouse infirmary did not mention Lily's tuberculosis in its handover to the asylum. They may have overlooked it or ignored it in the course of their preoccupation with her mental state. It is doubtful that Lily's physical illness trajectory could have been reversed, but for other people with less advanced or different illnesses, treatment in a general hospital might have secured a better outcome. Lily's transfer to an overcrowded asylum which lacked isolation facilities also jeopardised other patients who were put at risk of catching her infection. Lily died a few weeks later. Her post-mortem confirmed the diagnosis: "Both lungs riddled with tubercle with cavities of varying sizes in both lobes." 13

Lily's journey from community, via the observation ward and into the asylum raises many issues about the mental disorders suffered by people admitted as pauper lunatics. This chapter seeks to explore some of them. The chapter begins by touching on the stresses of wartime life in the community, even though the Lunacy Act did not permit asylums to undertake out-patient or community work. It then focusses on mental disorders more generally, but with special reference to the patients in the public lunatic asylums: classification; research; nature and nurture hypotheses; treatment and convalescence.

\section{Air Raids and Other War STRESSES IN THE COMMUNITY}

During air raids early in the war, while some people ran for their cellars, others flocked onto the streets to watch the airships illuminated by search lights and to see their shells exploding. Anticipation of further raids caused some people anxiety, nightmares, insomnia and exhaustion. There was real danger, but Freudian interpretations also circulated, relating to the airships' phallic shape. ${ }^{14}$

Medical historians interested in the First World War have tended to focus on shell shock or the population's physical health, as reflected in national agendas at that time. ${ }^{15}$ Concerning civilian mental health, there is little historical research about it, in contrast to much appertaining to it during the Second World War. Historical analysis about the latter provides some clues about issues likely to have been present in the earlier war, such as civilian morale, responses to threats of air raids and the presentation of symptoms. Edgar Jones and colleagues in their Second World War study, 
found that predictions of mass air raid neurosis failed to materialize: civilians proved more resilient than planners had predicted, largely because they had underestimated public adaptability and resourcefulness. ${ }^{16} \mathrm{Hazel}$ Croft, in a study of civilian neuroses also in the Second World War noted that wartime camaraderie, full employment, active roles in civil defence and war work may have assisted wellbeing. Reluctance to admit to mental symptoms which could be seen as personal failings, the incentive to be an ideal, stoical citizen, and that many people would not have taken their worries as a health matter to their family doctor, may have both concealed the true amount of mental disturbance and kept the sufferer away from mental institutions. ${ }^{17}$ Croft's and Jones' analyses cannot be directly extrapolated backwards to the First World War, but they provide some possible explanations in support of the data which point to relatively few civilians being admitted to asylums due to unmanageable mental stress.

Of a random sample of 49 First World War civilian admissions to Colney Hatch, Claybury, Hanwell and Napsbury, ${ }^{18}$ stress, worry, fright and fear relating to daily life in London were identified as presumed causes in five. On the one hand, this may be an under-estimate because attributing causes was an in-exact science and asylum records were incomplete. On the other hand, of these five, possibly three whose conditions were initially attributed to stress had other disorders to explain their symptoms. Lily was one. James $\mathrm{N}$ was another who was subsequently diagnosed with general paralysis of the insane (GPI, brain syphilis). He is discussed later in this chapter. Arabella M (Fig. 3.2), a 53-year-old house-

Fig. 3.2 Arabella $M$, admitted with "Worry and Zeppelin fright" (Photographs of female patients at Colney Hatch 1908-1918 $\mathrm{H} 12 / \mathrm{CH} / \mathrm{B} / 18 / 003$ LMA)

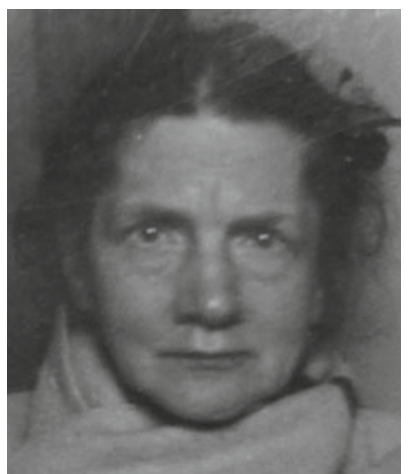


wife, was admitted to Colney Hatch, with mental distress attributed to "Worry and Zeppelin fright", but her case records also suggest overlap with physical illness. ${ }^{19}$

The figures do not suggest that the asylum population in the London area was overwhelmed with psychologically distressed patients. In contrast, in a study of the Denbigh Asylum serving north Wales, Pamela Michael identified 19 per cent of admissions in 1918 associated with "war worry". ${ }^{20}$ Fear of raids in Wales may have caused more mental disturbance than for Londoners who developed strategies to deal with them. Similarly, as Harry Bernstein, born in 1910 and growing up almost 200 miles from London in Stockport, Cheshire, wrote: "The German zeppelins were bombing London and fear hung over us constantly." 21

Threats other than bombs also created stress. Some people developed anxiety and depression fearful of the consequences for their loved ones fighting in the trenches or devastated by their deaths. For some women, keeping intensely busy was another way of coping, including making the most of new opportunities to work outside the home. ${ }^{22}$ For others changes in roles and employment, and consequent financial difficulties, were traumatic. For Louise F (Fig. 3.3), a single 34-year-old Turkish "enemy alien", a financial crisis precipitated her admission to Claybury.

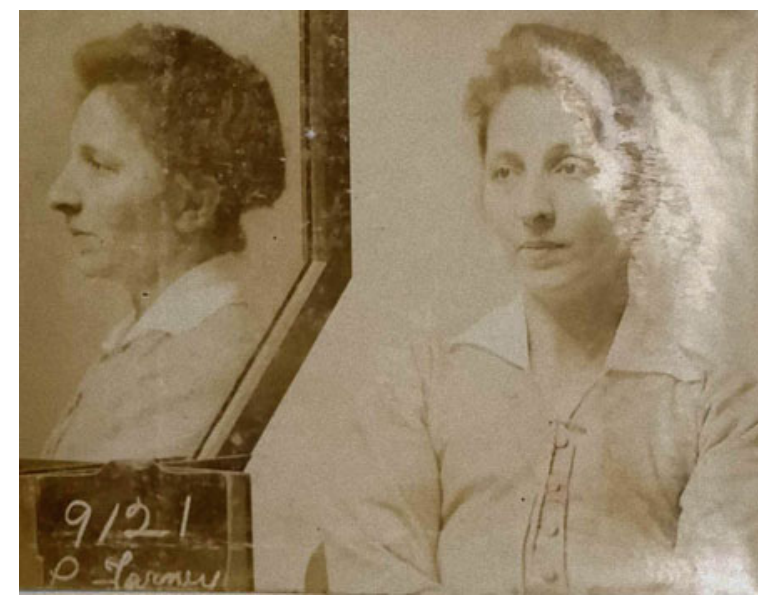

Fig. 3.3 Louise F, an enemy alien (Claybury: Female Patient Case Notes 1917; Redbridge Heritage Centre, 2020) 
Louise had worked in England for 12 years, but in 1917 she was unemployed, her status making work hard to find. She sold her belongings to support herself. Almost destitute, when the coal merchant failed to deliver her coal, she smashed his shop window in despair and anger. The magistrate sentenced her to a week in Brixton Prison from where she was released to the workhouse. There, she was distressed and refused to eat, and was certified for asylum admission. Six months later, she was discharged fully recovered via a Mental After Care Association convalescent house. ${ }^{23}$ The asylum had provided care and time for her to recover from her ordeal. She returned to work as a nurse and dress designer. ${ }^{24}$

Undoubtedly some people were admitted to asylums suffering directly from the effects of war time stress, but given the limited data collected during the war by the asylums' Board of Control ("the Board"), the patchiness of case notes, plus inaccuracies in specifying the causes of mental symptom and other factors affecting bed occupancy, it would be imprudent to estimate the number of asylum patients admitted directly and solely due to the stresses of war. Overall, asylum case notes suggest that they were admitted infrequently, and, as for Louise F, those whose symptoms were really due to stresses in civilian life, they improved and were discharged. This contrasts with the many admitted with life threatening or incurable mental and physical disorders.

\section{Understanding Mental Disorders: Classification}

Concerning the healthcare of sick people in England, psychiatrist Adolph Meyer, looking on from the USA, commented:

One comes closest to the truth about English medicine in saying that it's conceived as the art of healing, to which science is subordinated. Practical matters receive priority everywhere. ${ }^{25}$

Doctors were trained as apprentices to treat patients to the best of their ability guided by their professional ethics, with hypotheses less important. In asylum practice, the Lunacy Act undermined the tradition of medical empiricism, of helping people when they needed help. It introduced conflict for doctors between providing timely treatment when the sufferer sought it or needed it or might benefit from it, and delays because certification was only possible with more severe symptoms. Clinical records reveal patients' disabling psychiatric symptoms and the suffering of those 
admitted to the asylums. Sarah F's tortured expression indicated her anguish (Fig. 3.4). ${ }^{26}$ She, and others unwell due to mental disorders, required compassion and help in the broadest sense, regardless of theories and legalities.

Meyer's observation fits with Tracy Loughran's argument that "British doctors were self-consciously proud of the empiricism of their medical tradition", in contrast to the "French and German taste for abstract theorisation." 27 Nevertheless, British psychiatrists were active in debates on some philosophical questions, such as the nature of insanity. There was no accepted single definition; all were unsatisfactory, vague and subjective with their value debated and with unclear dividing lines between normal, abnormal and eccentricity. ${ }^{28}$ The Lunacy Act was unhelpful, stating that "'Lunatic' means an idiot or person of unsound mind". ${ }^{29}$ Psychiatrist Charles Mercier wrote on the difficulties of defining insanity:

No doubt we all have a certain vague notion in our minds, but the fact that we cannot put the notion into words shows that the notion is but vague and cloudy, sadly lacking in precision and definiteness.

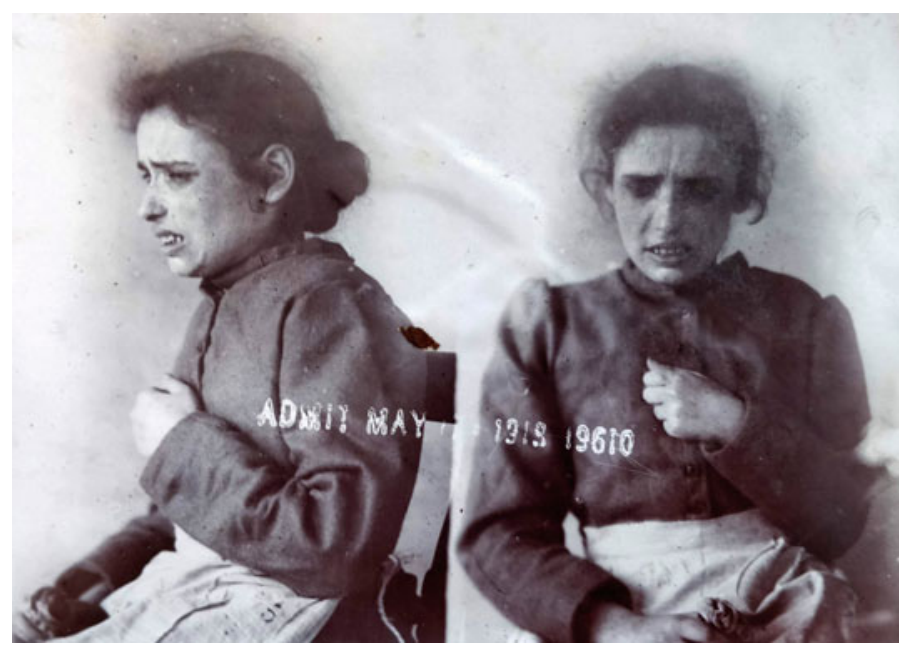

Fig. 3.4 Sarah F, in need of help (Photographs of female patients at Colney Hatch 1918-1920 H12/CH/B/18/004 LMA) 
With his own characteristic eccentricity and boldness, lack of clarity did not stop him declaring that his own equally vague definition of insanity, an all-encompassing disorder of mind and conduct, was the best. ${ }^{30}$ John Turner, medical superintendent of the Essex County Asylum at Brentwood, aimed for more precision and defined a "certifiable lunatic" as "one whose conduct (owing to disease) is persistently out of harmony with his environment, and who is, or may become, a source of harm to himself or a danger or annoyance to the community." 31 It too was inadequate, raising questions about the meaning of psychiatric "disease" and introducing social factors which could vary across place and time. Another physician, Edward Younger, advised that a doctor giving evidence in a law court should refuse to define insanity. ${ }^{32}$ The difficulty of defining it was also a concern outside the medical profession. Earl Russell, perhaps influenced by personal experience, his own behaviours from time to time being on the fringes of public acceptability, commented in the House of Lords in 1914 that "whether a person is sane or insane is one of the most difficult matters that doctors have to decide, the dividing line being so fine". 33

Not only was the overall definition of insanity inadequate, but classifying the array of different disorders within it was likewise problematic. Disease classification was founded on the system of the biological sciences. Meaningful categories depended upon whether symptoms were consistent across time and culture: if they had a biological basis they would exist in the same form in different places and times. This bore out the need to identify the form of symptoms, rather than their culture-bound content which varied across time and place, influenced by contemporary cultural issues and belief systems. ${ }^{34}$ Classification was challenging for psychiatric symptoms which often lacked a clear underlying physical pathology, but identifying the type of disorder was important as each type would be expected to behave in a characteristic way with regard to causes, prognoses and treatments. Without clear physical pathology, psychiatric classification was (and is) based on clinicans' expertise in psychopathology, influenced by social and cultural expectations of disease and normality. ${ }^{35}$ A degree of subjectivity was inevitable. Recognising these uncertainties could also contribute to public fear of wrongful confinement due to inaccurate medical assessments. ${ }^{36}$

Classification of psychiatric disorders was not just of interest in England, but was under consideration in Germany. Many psychiatrists outside Germany desired to emulate Emil Kraepelin's “clinic”, 
but responses to his psychiatric classification varied. ${ }^{37}$ Meyer initially welcomed Kraepelin's diagnostic classification, particularly concerning manic-depression and dementia praecox (later known as schizophrenia), as the break-through which psychiatry was waiting for, but he later criticised it for being too neurological and failing to take into account the context of the patient's life story. ${ }^{38}$ Mercier accused his colleagues of following "Continental fashion" 39 and Havelock Ellis, a physician, better known for his studies on sexuality, acknowledged the snags of psychiatric classification generally and Kraepelin's classification in particular:

It is impossible to consider the miscellaneous cases brought together by Kraepelin under the heading of manic-depressive insanity as a single disease....We learn nothing by placing a case in a "natural classification" which has no existence, and can have no existence, in the sense understood by Kraepelin. ${ }^{40}$

The war may have influenced negativity towards German psychiatric research. Near the end of the war, president of the American MedicoPsychological Association, James Anglin, described his colleagues as "infatuated with German pseudo-discoveries". Subjectivity associated with personal anguish may have clouded his views, mentioning in that lecture, the death of his eldest son at Vimy Ridge, his second a "permanent cripple", a third still fighting, and another preparing to travel to war. $^{41}$

During the First World War and through to today, uncertainties in knowledge and understanding reflect different and evolving psychiatric classification systems and a thirst to find meaning, order and clinical guidance. In the context of many divergent views, the Board classified mental disorders based on their presumed causes, in the hope that it could reveal information useful for prevention and treatment. ${ }^{42}$ Regarding causation, psychiatrist Bernard Hollander drew attention to the importance of environmental and social factors, Mercier emphasised concepts drawn from understandings about physical illness, while others favoured inherited risks. ${ }^{43}$ A search for causes fitted with the belief that mental disease originated beyond skull and brain, in line with recent discoveries of invisible causes of physical disease identified through studies of physiology, pathology and bacteriology. ${ }^{44}$ This was also compatible with observations that physical and mental disturbances overlapped, as in Lily's case, and that they had common causes, despite mechanisms remaining obscure. ${ }^{45}$ 
These overlaps encouraged the practice of carrying out post-mortems on almost all asylum patients (discussed further in Chapter 7): if causes could not be determined during life, it was appropriate to search for them after death. Biological explanations also had other advantages, such as the potential to avoid blaming patients for their own mental problems and reducing punitive responses to their otherwise inexplicable behaviours. The colloquialism "pull yourself together" was known by the mid-nineteenth century, ${ }^{46}$ indicating that the speaker believed that a mentally disturbed person could immediately revert to normal. That was no truer for severe mental than physical illness: as Dr. Montagu Lomax advised in his critique of war time psychiatric practice: "it is as rational to punish a mental patient for refractory behaviour as it would be to punish a typhoid fever case for a rise in temperature." 47

For each patient admitted, the Board pragmatically sought to record "predisposing" and "exciting" factors which could occur alone or in combination. These fitted with the need to disentangle multiple theories of causation, but as indicated for Lily R, Arabella M and James N, attributing causation was prone to inaccuracies. Before the war, from 1907 to 1911, the Board identified the main causes of admission to be alcohol, prolonged mental stress, "insane heredity", senility, GPI and epilepsy, with some gender variation for each (Table 3.1). ${ }^{48}$ Pre-war data is the best available because the Board discontinued its multi-page tabular compilations of causation as part of reducing the administrative workload

Table 3.1 Yearly average of the total incidence of each cause (for first admissions) assigned without any correlated cause or factor, 1907-1911

\begin{tabular}{lcrrrr}
\hline & \multicolumn{3}{c}{ Males } & & \multicolumn{2}{c}{ Females } \\
\cline { 2 - 3 } \cline { 5 - 6 } & $n$ & $\%$ & & $n$ & $\%$ \\
\hline Alcohol & 707 & 20.5 & & 311 & 8.5 \\
Prolonged mental stress & 567 & 16.5 & & 642 & 17.6 \\
Insane heredity & 399 & 11.5 & & 538 & 14.7 \\
Senility & 328 & 9.5 & & 416 & 11.4 \\
Acquired syphilis (GPI) & 311 & 9.0 & & 40 & 1.1 \\
Epilepsy & 220 & 6.4 & & 165 & 4.5 \\
\hline Total & 3443 & & 3649 & \\
\hline
\end{tabular}

Source Commissioners in Lunacy, Tables xvii (male), xviii (female): causes of first admissions, excluding to idiot establishments, 1907-1911, MH51/687 TNA. 
during the war. Of note, very few people were admitted with so-called "moral insanity", a subject which has entered recent public discourse through early twenty-first century novels depicting women incarcerated for no other reason than having given birth to an illegitimate child. ${ }^{49}$ There is little evidence that unmarried mothers were admitted to asylums in the war years unless they also had mental symptoms, or they fell under the rules of the Mental Deficiency Act (MDA) 1913. The MDA, but not the Lunacy Act, obliged authorities to admit to an institution a woman known to be mentally defective "who is in receipt of poor law relief at the time of giving birth to an illegitimate child, or when pregnant of such child". ${ }^{50}$ Objectives of this rule included preventing further pregnancies and preserving the woman's health and the ratepayers' pockets. Punishment was not integral to the plan, on the assumption that the pregnancies resulted from vulnerable women being exploited by men. The women tended to be admitted to mental deficiency institutions, lunatic asylums being considered inappropriate for their long-term detention.

Despite treatment implications derived from classifications based on symptoms or causation, they had little part in informing the organisation of asylums. Asylums adopted patient classifications based on "conduct, habits and bodily states" to place patients into "infirmary", "quiet", or "troublesome" wards. ${ }^{51}$ These categories often had little to do with the individual's treatment or prognosis, but were convenient for the asylum. Some new patients were placed on wards appropriate to their needs, but others, such as some who were very disturbed, could be placed on wards with the most difficult to manage long-stay patients who had different disorders and therapeutic needs. ${ }^{52}$ If the acutely disturbed new patient settled while on a ward of mainly long-stay patients suffering persistent behavioural symptoms, he could be overlooked relative to those who demanded more attention. Alternatively, if a new patient saw that difficult behaviours attracted staff attention, this could accentuate his disturbances, which could bring about the assumption that he had a similar chronic disorder. Either way, the new patient would be disadvantaged. The outspoken psychiatrist Lionel Weatherly criticised the combination of inadequate classification together with overcrowding. ${ }^{53}$ The worst scenario, according to Nurse Jane Dagg who gave evidence to the postwar Cobb Inquiry, was overcrowding with no classification, as in the asylum where she had worked. ${ }^{54}$ Little attention was paid to the merits of clinically focussed classifications or the understanding that acute disorders were more likely to improve than chronic. According to Weatherly, and to 
Herbert Ellis, a magistrate and asylum management "visiting" committee member, the way patients were classified in asylums was influenced by short term financial considerations. ${ }^{55}$

\section{Researching Mental Conditions}

"Scientific" classification of mental disorders was an aid to undertaking meaningful research, and its haphazard utilisation may have been one factor contributing to Hugh Freeman's analysis that British psychiatrists produced relatively little of importance from their research. ${ }^{56}$ Despite this, the Journal of Mental Science (JMS $),{ }^{57}$ published by the MedicoPsychological Association (MPA), brought together much research from home and abroad, pointing to diverse concerns and priorities, including a tendency for researchers to grapple with somatic, bodily processes thought to be associated with mental disorders, rather than the mental disorders themselves. Reports in the JMS on "vaccine therapeutics", dysentery, enteric fever (typhoid) and inflammation, read more like a journal of microbiology, rather than psychiatry. ${ }^{58}$ Alongside the $J M S$, the Lancet, published for a broad medical readership, indicated other psychiatric preoccupations, including shell shock, lunacy legislation, ${ }^{59}$ sedative medication ${ }^{60}$ and "sexual perversion". ${ }^{61}$ Weighing up the multiplicity of often contradictory research findings was far from straight forward, itself a demonstration of the lack of a secure scientific knowledge-base for clinical, policy and administrative decision making. Randomised controlled trials were not yet established in medical research, and together with embryonic statistical methodology, these factors often made conclusions hard to draw. George Savage commented that new discoveries challenged earlier certainties: "we must 'wait and see'; that we are prepared to follow truth where it leads, and that a dim light is better than none in such darkness as the realms of life and consciousness." 62

Another factor contributing to the paucity of psychiatric research in England was the lack of an academic backbone for psychiatry, in contrast to the world-leaders in the field in German speaking countries. ${ }^{63}$ Also, in contrast to the trend in much of western Europe, English-speaking countries separated the medical specialties of psychiatry (brain: mainly mental and behavioural manifestations) and neurology (brain: mainly bodily manifestations), despite much clinical overlap. British neurology became a discipline with high prestige and impressive clinical and scientific standards, in contrast to psychiatry. Many neurologists worked in 
private practice and had time for research. Most lacked experience of, or clinical responsibility for, patients in asylums although their research was pertinent to them. Neurologist John Hughlings Jackson, for example, researched epilepsy, yet he was unlikely to look after people with the severest forms of the disorder who frequently resided in asylums. In contrast to neurological research, little took place in asylums which were cut off, geographically and intellectually, at a distance from teaching hospitals and universities, and with their staff submerged by heavy workloads.

Despite lack of participation in research, as the content of the JMS indicated, psychiatrists sought answers to many of the problems faced in their clinical work. In 1912, almost every asylum authority in England and Wales sent delegates to a conference in London to discuss improving research into mental diseases. The conference stressed the importance of government funding for research (as provided in Germany) and informed the Prime Minister and Chancellor of the Exchequer of that. ${ }^{64}$ Just before war broke out, the Board and MPA planned further discussions on taking research forward. ${ }^{65}$ Later in 1914 , the Treasury granted the Board $£ 1500$ to spend on research. ${ }^{66}$ This was a pitiful proportion of the overall government medical research budget of $£ 58,000 .{ }^{67}$ The many applications for funding suggested interest in undertaking psychiatric research but limited expertise to carry it out. ${ }^{68}$ Around the beginning of the war, the JMS and the Board reported on progress made in research from the asylums, including on the perennial enigmas of asylum dysentery, biological markers of insanities, and the relationship between insanity and mental deficiency. ${ }^{69}$ Research on mental disorders was challenging, but financial priorities may have contributed to John Keay's frustration: "Why should insanity be left behind when so much forward endeavour is made in general medicine?". ${ }^{70}$

Most psychiatric research ceased during the war but a fresh clinical challenge loomed at its end: to unravel the new, disabling condition of encephalitis lethargica, later immortalised in Oliver Sacks' Awakenings ${ }^{71}$ and Harold Pinter's $A$ Kind of Alaska. ${ }^{72}$ Despite an early consensus that the disorder resulted from the 1918-1919 influenza pandemic, evaluating the evidence was tricky and the hypothesis was gradually replaced by scepticism. ${ }^{73}$ 


\section{GPi: Clinical Challenge, Research and Cautious Responses to InNOVATION}

Research guided by the desire to identify physical causes of mental disorders had direct relevance to the welfare of patients in the asylums. General paralysis of the insane (GPI) provides an illustration of this. GPI could be difficult to diagnose from the patient's history and mental state examination, hardly surprising given that its symptoms were multiple and variable. The Wassermann blood test introduced in 1907 helped, but could give false positives. In 1913, Noguchi identified the spirochaete treponema pallidum, a bacterium, in the cerebro-spinal fluid surrounding the brain, thus verifying that syphilis caused GPI. Cautious psychiatrists in England, however, remained wary of both the Wassermann test, which moved slowly and erratically into asylum use, ${ }^{74}$ and of Noguchi's evidence, acknowledging in 1918 that the spirochaete "probably" caused GPI. ${ }^{75}$

Some patients with GPI were women but most were men, often described as "powerful, hearty men, who had lived hard and never ailed...had 'burnt the candle at both ends,' and had led irregular if not debauched lives". ${ }^{76}$ Syphilis was acquired sexually, but the spirochaete could spread to many body organs. When in the brain, its array of symptoms often included delusions of grandeur, which could result in financial ruin for a family. ${ }^{77}$ Salvarsan, an arsenic-based drug, could cure bodily syphilis ${ }^{78}$ but had no effect on the spirochaetes once they had entered the brain. ${ }^{79}$ Some men so feared developing GPI that, after an "indiscretion with a woman", they developed another psychiatric disorder-syphilophobia-which could "drift into insanity" or lead to suicide. ${ }^{80}$

GPI was inevitably fatal: disinhibited behaviour, restlessness, seizures and difficulty swallowing food were associated with an undignified asylum death, such for Emma Sarah M who gave birth at Claybury in November 1914 while suffering from seizures caused by the disorder. Her baby survived, and, aware of the stigma derived from insanity, the asylum arranged a birth certificate which did not state the place of birth. ${ }^{81}$ James $\mathrm{N}$, a more typical patient with GPI, was a single, 34-year-old clothing factory machinist, ${ }^{82}$ admitted to Colney Hatch. He was described as suffering from stress, and was sullen, melancholic, and restless. He refused food, likely associated with his "delusions that he is 'full up' to the neck and that he cannot pass his water or faeces." He developed seizures and died shortly after admission. ${ }^{83}$ 
Given the progressive and fatal nature of GPI, finding effective treatment was essential, even if the treatment itself had risks. During the war, Julius Wagner-Jauregg in Vienna, inoculated patients with malaria parasites to induce high fevers to kill the heat-sensitive spirochetes. He published his findings in $1919 .{ }^{84}$ Malaria treatment was dangerous, but until penicillin became available nearly three decades later, it was the only hope. Malaria treatment, alongside other clinical innovations, received a characteristically cautious reception from psychiatrists in England. Drastic treatments in psychiatry were appearing around the same time as risky interventions for other fatal disorders. William Halstead, for example, introduced the "radical" mastectomy for breast cancer, in the belief that cure was more likely with ever wider surgical resection. ${ }^{85}$

Caution and scepticism about innovative clinical methods was a double-edged sword. On the one hand it could prevent harm by avoiding insufficiently proven new methods, and on the other, it could cause harm by rejecting new and effective procedures. In contrast to the conservative approach of psychiatrists in England, and in the context of multiple hypotheses about infections combined with ideas about the benefits of radical treatments, less conformist colleagues risked generating over-zealous and unregulated treatments. This happened in the USA. Henry Cotton at Trenton State Asylum instigated a programme of radical surgery for psychiatric patients, to remove various organs harbouring suspected "focal infection" which supposedly produced or perpetuated their mental disorder. ${ }^{86}$ Some of Cotton's patients, probably coincidentally, recovered mentally after his interventions, but evaluation of the treatment neglected the overall balance between healing and harm, including death. Surgery for focal infection, however, was not confined to psychiatry. It was also used for preventing physical disorders, such as "routine" tonsillectomy in children, once commonplace but later discredited as a prophylactic public health measure. ${ }^{87}$ Despite some admiration for Cotton's work in the UK, his regime was not replicated on this side of the Atlantic where psychiatrists were arguably less innovative and more restrained in their treatments. ${ }^{88}$

English psychiatrists weighed up risks in a generally risk-averse asylum culture. They took clinical risks from time to time, usually in desperation. Tube feeding, is one example, undertaken on patients usually gravely ill, likely to have severe mental illness, stupor, food refusal and dehydration, all compounding the risks of the feeding. ${ }^{89}$ English psychiatrists also adopted some fashions or fads used for treating physical illness. The Royal 
Society of Medicine (RSM), alongside its more traditional medical and surgical sections, had a "Section of Electrotherapeutics", which advocated the use of X-rays and therapeutic electricity, the latter compatible with the understanding of electrical impulses in the nervous system. It also had a "Section of Balneology and Climatology" which included therapeutic bathing considered beneficial for many physical and mental disorders. Accepted but unproven, balneological therapeutic measures in asylums included prolonged warm baths for "motor excitement", Turkish baths for "simple melancholia" and brief cold showers or baths "to overcome certain resistances in the nervous system" in stupor. ${ }^{90}$

Use of electricity became an attractive therapeutic tool, acceptable to professionals and public, and of interest even to cautious asylum doctors. Shifting from simple therapeutic bathing, more risky methods evolved, such as combining bathing plus electricity in an "electric bath". ${ }^{91}$ This was believed to stimulate stuporose patients and to help excretion of toxins in schizophrenia. Using baths specially constructed from earthenware or wood, with a large flat copper electrode covered with towelling at each end connected to a battery, the procedure was considered safe. Twenty-two-year-old Annie $\mathrm{H}$ reportedly benefitted from electric baths, then died suddenly after a treatment. According to the Board, procedures had been followed correctly, staff supervised the bathing and applied the correct current. At post-mortem Annie was found to have "status lymphaticus", characterised by large thymus, thyroid and lymph glands, and bone marrow hyperplasia. The coroner concluded that her death was due to sudden paralysis of the heart due to status lymphaticus, unrelated to the bath. ${ }^{92}$

But what was status lymphaticus? Detected at post-mortem, usually after a sudden death when under medical care, its incidence increased in parallel with the use of anaesthetics. It was a convenient post-mortem diagnosis. For bereaved relatives, scientific explanations were more acceptable than "a visitation of God" in an increasingly secular society. It also provided a way for coroners to justify a verdict of death from natural causes, much to the relief of the medical profession. The existence of status lymphaticus was debated during the first half of the twentieth century, then disappeared from the medical corpus. ${ }^{93}$ In reality, it never existed. It deflected blame for medical failure onto the patient. It was a diagnostic label created to fulfil professional and social needs. In this instance, it primarily protected the medical profession. Postmortem findings were probably extremes of normal, modified by age, 
and mis-interpreted as abnormal, but with credibility compounded by the ferocious search for physical aetiologies. ${ }^{94}$

\section{Nature ANd Nurture: Biological, SOCIAL AND PSYCHOLOGICAL}

In their style of pragmatic and cautious consideration, psychiatrists in England tried to fathom out which vulnerabilities predisposed to mental breakdown, and why people responded differently to similar hazards, such as infective organisms, social circumstances, alcohol, or war stresses. In their clinical practice, according to Loughran, they took a "magpie approach", choosing apparently useful aspects of particular theories without any one predominating. ${ }^{95}$ Meyer's work also advocated a combined biological, psychological and social ("bio-psycho-social") approach to mental disorders, and looked beyond single issues and promoted an eclectic approach to treatment. ${ }^{96}$ There was little consensus on the relative contributions of heredity, brain disease, infection, psychosocial, spiritual and other medical and non-medical factors to causing mental disorders. Debates on causes of mental disorder in civilian patients dovetailed with those concerning aetiology of shell shock-commotion, emotion or both - which continued throughout the war. ${ }^{97}$ Baffled by the lack of clarity on causation of mental disorders, the Ministry of Pensions asked the Board for a simple rule to help clerical staff determine pension eligibility for mentally disturbed soldiers: the Board declined to provide one. ${ }^{98}$

Prominent biological theories of heredity included "degeneration", a downwards movement of health and wellbeing of individuals, families and society. Degeneration theories had punctuated Western philosophy, politics and religion for centuries, ${ }^{99}$ and according to George Rosen, ideas included that once degeneracy set in, "the various generations of a family went inexorably to their doom."100 Bénédict Morel introduced his Dégénérescence hypothesis in the 1850s, using it to explain mental and social disturbances. ${ }^{101}$ The theory gained ground, among public, politicians, physicians and scientists including the influential psychiatrist Henry Maudsley who regarded degeneration as a threat to the prevailing culture of the British Empire and to European "civilisation". ${ }^{102}$ As well as being founded on dubious scientific evidence, degeneration had racist and eugenic interpretations. 
Benjamin Seebohm Rowntree proposed an alternative causal explanation for the numerous problems experienced by working class people: poverty. ${ }^{103}$ Since poverty tended to affect whole families, it complicated differentiating between nature and nurture, intrinsic and extrinsic causes. In contrast to poverty being a primary cause, degeneration provided excuses, convenient for the elite, for failures of society. Blaming the constitution of the individual rather than intervening to alleviate poverty assuaged the consciences of the ruling classes. Degeneration theory, by its message of inevitable decline, could also discourage public interest in people in asylums whose problems were attributed to it. It added to stigma and gave a sense of hopelessness, a lost cause.

Degeneration had other effects on attitudes and practices in asylums. It was a reassuring and comforting "scientific" explanation for psychiatrists who failed to cure their patients. Nevertheless, many psychiatrists were also aware that theories of degeneration or heredity did not always hold: children of insane parents did not necessarily become insane or show other predicted decline or deficits. ${ }^{104}$ Ideas of degeneration or heredity, or as Bill Bynum characterised it, a "concept of progressive hereditary degeneration", 105 did not deter psychiatrists from treating their patients labelled in this way, nor did it preclude rehabilitation, discharge or normal life events, as in the case of Dorothea $S$, a 33-year-old a single woman from Islington who assisted her mother Adelaide to run a boarding house before her admission to Colney Hatch. ${ }^{106}$ Discharged after 18-months, labelled as suffering from "Mental Stress. Insane Heredity", three months later she married George $\mathrm{M}$, a clerical worker, one of the residents of the boarding house. ${ }^{107}$

Although degeneracy and hereditary labels were ignored in terms of prognosis and treatment for individuals, according to Richard Walter, in his essay "What became of the degenerate?", eugenicists "adopted many of the claims of the devotees of degeneration." 108 Eugenics encouraged the reproduction of people with "desirable" traits, and discouraged reproduction of those with "undesirable". Eugenic proposals included sterilising the "unfit", such as insane people. ${ }^{109}$ The war added other dimensions to the degeneration debate: if British soldiers were not degenerate, why did so many succumb to shell shock? Conversely, if they were degenerate, how did they win the war? Edward Shorter argued that degeneration theories were being discredited within psychiatry before the war, ${ }^{110}$ although in England psychiatrists had never unanimously accepted them. Daniel Pick argued that the war "put paid to the dominance of 
dégénérescence within psychiatry and shifted the language of debate."111 Nevertheless, the Board received the following statement before it was put to a meeting of the Board of Guardians at Sevenoaks in Kent in 1918:

The War has taken an appalling toll on the lives of the noblest and best of our manhood, yet, today, too little or nothing is being done to safeguard the Race from the menace of the weak and dependent who constitute an ever growing financial burden on the Ratepayers, who, in themselves, are becoming yearly less able to bear the strain. 112

The Board of Control stood its ground against eugenic proposals, including from psychiatrists, to sterilise insane patients, and against public opinion which surfaced advocating for it. ${ }^{113}$ The war may have undermined degeneration theories, but related ideas around eugenics continued.

Biological and degeneration theories had the potential to profoundly affect the wellbeing of patients, but over-enthusiasm in that direction was tempered by the conservative culture of the medical profession and ideas on causes and treatment of mental disturbance arising from new mind-focussed disciplines. Concepts of psychology, psychoanalysis, and suggestive therapies were expounded by new professional groupings. ${ }^{114}$ Some psychiatrists, such as Bernard Hart, medical superintendent of a private asylum and lecturer at University College Hospital, London, advocated for their methods as integral to the practice of psychiatry. ${ }^{115}$ Lomax also recommended a psychological approach, such as placating and reasoning with patients to modify their behaviours. ${ }^{116}$ At a basic level of psycho-social treatment, asylum staff were meant to demonstrate exemplary conduct to help correct patients' behavioural disturbances. While some staff used psychological skills acquired from experience, such as to diffuse a difficult ward situation, more widespread use of psychological methods would require more, and better trained, staff. ${ }^{117}$

Psychoanalysis gave new perspectives on causes and treatment of mental distress. It became better known in England concurrent with the war. Sigmund Freud's theories were translated into English by Ernest Jones, his disciple in England. ${ }^{118}$ Carl Jung's British followers began promoting his views, arguing that his more optimistic and less sexually oriented conception of the unconscious was preferable to Freud's. However, mid-war, the JMS gave an airing to French zoologist Yves Delage who likened Freud's theories to an army or infectious disorder: 
This new affection, which threatens to invade France, had its birth in Austria, at Vienna, some twenty years ago. Its progress, at first very slow, soon became rapid, and the spread of the evil generally now knows no pause....it would be imprudent to allow ourselves to be lulled to sleep under a delusive sense of security. ${ }^{119}$

Mercier also ridiculed Freud's theories of sexual excess, repressed complexes and infantile sexual longings, and asserted: "I do not hold that there is only one cause of mental disease. If I did so hold, I should be little better than a psycho-analyst." ${ }^{20}$ Some doctors found psychoanalytic theories meaningful in their private work and when working with shell-shocked patients, such as WHR Rivers whose broadly psychological approach included catharsis, re-education, faith and suggestion. ${ }^{121}$ However, as with much of psychiatric practice, clinicians used different methods. Lewis Yealland, for example, in contrast to Rivers, advocated a "disciplinary" and physical approach to shell shock and administered electric shocks. ${ }^{122}$ More widely, psychoanalytic concepts and methods gained popularity mainly among the educated lay public. ${ }^{123}$ Psychological and psychotherapeutic processes were far-removed from asylum practices even though they fitted with ideals of practice recommended by psychiatrists, that treatment for insanity must be humane and "individual". 124

\section{Treatments: Moral ANd Medical, RESTRAINT AND SECLUSION}

Within the asylums, despite psychiatric recommendations for treatment to be individual and commenced as early as possible, just as for physical illnesses, ${ }^{125}$ achieving this was beyond imagination. With the country's military needs taking precedence asylums were short staffed, losing the precious commodity of staff time to build therapeutic relationships and use their existing psychological skills to manage the most difficult, and potentially dangerous, patients. Lomax wrote: "To crowd lunatics into asylums is worse than useless unless we have some recognized principles of treating them when once we have got them there". ${ }^{126}$ At the Cobb Inquiry, one former patient said: "If a man gets better it is in spite of the treatment, not because of it". ${ }^{127}$ Another declared that in the asylum where he was admitted "There was no mental treatment at all". ${ }^{28}$ 
"Moral" treatment, which emphasised achieving mental and physical well-being, emerged as an ideal way of treating psychiatric disturbance, but it was never adopted widely. It was particularly hard to implement in larger, impersonal, overcrowded and inadequately staffed asylums. The method was attributed to William Tuke, the non-medical founder of the York Retreat. Despite support from psychiatrists, Bynum argued that "Professional, social, and economic considerations coloured their own judgments and tempered the enthusiasm they showed towards moral therapy". They were prepared to adopt features of it into their own therapeutic programmes, but not to jettison their medical models. ${ }^{129}$ Alongside medical models and some practices inspired by moral treatment, asylums used many other approaches including careful attention and watchfulness, dealing with "dirty habits" (incontinence), and preventing physical injury or suicide, or death due to "maniacal exhaustion, an ending which is looked upon in asylums as being something of an opprobrium to those who have had charge of the case". ${ }^{130}$

Curative medications were generally unavailable for psychiatric and physical disorders. The psycho-pharmacopoeia was limited. Iron, quinine, arsenic, and strychnine were used as tonics. ${ }^{131}$ A range of sedatives were available, with lack of consensus on whether to use them, which ones, and at what dosage. ${ }^{132}$ Suggested drug treatments were often accompanied by warnings of their limited usefulness and toxicity. ${ }^{133}$ Relying on imported medication, which was sometimes delayed at the docks during the war, ${ }^{134}$ could have benefits and drawbacks for patients.

Laxatives were an ancient remedy for mental disturbance still within the psycho-pharmacopoeia. John Haslam, an eighteenth-century physician, referred to laxatives as "cathartics", the cleansing process of catharsis referring to purging bowels or mind. ${ }^{135}$ They were also used to sedate, in the sense that profuse diarrhoea would temporarily weaken a patient, rendering him less liable to aggressive outbursts. Some doctors prescribed tiny doses of the laxative croton oil, up to $1 \mathrm{minim}$, the volume of a single drop of water, for constipation in patients who would not, or could not, cooperate with taking medication. ${ }^{136}$ However, the tiny volume also made croton oil liable to misuse, easy for staff to dispense on a whim or conceal in food or drink. Weatherly and Lomax alleged that potent laxatives, particularly croton oil, were given punitively without the dose being documented. ${ }^{137}$ The Cobb Inquiry investigated this allegation. It obtained records of purchases of croton oil at several asylums during 
1919. Prestwich, where Lomas had worked, purchased around 6500 minims, compared to 480 minims at Colney Hatch and none at other asylums. ${ }^{138}$ Although drug purchases depended upon how much the asylum had in stock, this was unlikely to account for the enormous differences. Neither could asylum size nor different types of illness or symptoms account for it, adding weight to the suspicion that some asylums used croton oil to punish, exhaust and sedate. Punitive practices may have been deliberately malicious, but could also have reflected lack of training and a despairing staff body who could not cope with the demands placed upon them (see Chapter 4).

Lomax agreed with psychiatrist William Stoddart that hefty sedation was "a refined substitute for hitting [the patient] on the head with a club."139 Another term for using medication to calm disturbed behaviour was "chemical restraint", with controlling effects comparable to "manual restraint" which required person to person contact or "mechanical restraint" which required equipment. Manual and chemical methods were usually initiated by ward staff in response to a crisis. These methods were not formally monitored but there were guidelines to ensure safety of both parties: "A violent patient must be overcome by weight of numbers and never by blows or any such form of retaliation" wrote Stoddart. ${ }^{140}$ However, unregulated and transitory, chemical and manual restraint could be secretive, abusive and punitive, and manual restraint could cause severe injuries (see Chapter 8).

By the war, early forms of mechanical restraint such as chains and shackles had been replaced by devices usually of cloth or leather, such as straitjackets and strong dresses made of very thick material and fastened at the back with sleeves which could be tied to the patient's torso. Jane Hamlett and Lesley Hoskins, in their study of asylum clothing, explained that restraint in a strong dress was "theoretically, a means of management and a treatment rather than a punishment but it did mark out 'difficult' patients and was certainly open to overuse or abuse by ward staff."141 Mechanical restraint could be applied for prolonged periods and was known to be used punitively, hence it was monitored by the Board under the Lunacy Act. ${ }^{142}$ A senior staff member needed to authorise the procedure, to document the reasons for using it and the duration of use. ${ }^{143}$ Another method of control was seclusion, with reasons for monitoring similar to those for mechanical restraint. Lomax and Stoddart disapproved of restraint and seclusion generally, and instead advocated 
taking a disturbed patient out of doors to calm down, giving him a football, ${ }^{144}$ or "turning him into the garden by himself and keeping him there till his aggressiveness has blown over". ${ }^{145}$ Restraint and seclusion methods were commonplace during the war, as they were less labour intensive for staff than finding out the cause of a patient's restlessness, or providing social or psychological calming alternatives. ${ }^{146}$

Some asylums used either mechanical restraint or seclusion, some both, others neither. ${ }^{147}$ Some differences in recorded usage may be accounted for by furtive completion of records. ${ }^{148}$ At Claybury, for example, medical superintendent Robert Armstrong-Jones reported to his committee that when patient Harriet $\mathrm{R}$ was wrapped in a wet blanket, a recognised means of mechanical restraint, "her limbs had been quite free to move, and therefore the case had not been entered in the register", ${ }^{149}$ despite rules that the reasons for using it had to be documented rather than the outcome of doing so. Soon after this, the Board inspected Claybury and commended it for not using mechanical restraint. ${ }^{150}$ This sequence of events suggests that using methods of which the Board disapproved, encouraged deception, left the Board unaware of the extent of their use, and maintained appearances of good practice. Weatherly reflected on restraint procedures: "Whenever I see in the reports of the Commissioners the statement, "We are glad to see that there is no record of mechanical restraint," I often wonder what substitute has been used". ${ }^{151} \mathrm{He}$ also wrote:

Nothing, to my mind, is worse than to see a suicidal patient struggling with two or three nurses or attendants, and I have often been told by such patients how much they appreciated the kindly supervised mechanical restraint that I had ordered. ${ }^{152}$

Perhaps self-congratulatory, and although his opinion was contrary to the Lunacy Act and the official standpoint of the Board, others agreed with him that the type of restraint was not as important as using it humanely. ${ }^{153}$ Another method of mechanical restraint which by-passed official gaze was to sit particularly difficult patients against a wall with a heavy table pushed close in front of them, without amusement or employment, only allowing them out to use the lavatory. In this way, one attendant could observe several difficult patients. Lomax described this 
as a "brutalizing form of restraint", "an inhuman device to save attendants trouble". 154 Established practices which made life easier for the staff persisted even when condemned as cruel: placing patients "behind the table" continued at Prestwich into the 1950s, according to a staff member witness speaking in an oral history interview. ${ }^{155}$

Seclusion was meant to provide "time-out", a cooling-off period for extremely disturbed people, but it could also be used punitively, resembling solitary confinement in prisons. Some seclusion rooms were padded, and many were unheated and lacked light and ventilation. Furniture was attached to the floor to prevent it being used to harm self or others. Each room generally had an observation window or peep hole in the door which was openable only from the outside. ${ }^{156}$ Lomax advocated having an attendant always outside the door to avoid the patients" "horror of loneliness and darkness which make them worse."157 In an autobiographical account of his experience in an Australian asylum, Mr. D Davidson described his isolation in a "cell" with an "eye-hole" through which a tall man occasionally squinted at him. Davidson linked his isolation and observation to the worsening of his terrifying beliefs that he would be tortured and killed. ${ }^{158}$ Another patient, James Scott, wrote about "padded cells", and drew one with a patient naked inside (Fig. 3.5). It is unclear whether the "hideous" sounds he referred to were the reason for, or outcome of, the seclusion:

The padded cells in an asylum are the most dreadful places imaginable; and the sounds which emanate from them, customarily, are hideous. I fervently ask the Almighty to spare me from ever again hearing such soul haunting noises, blasphemies, obscenities, cries and moans, as those which I so often heard during my four years imprisonment in the awful institution of which I am now disclosing the secrets. ${ }^{159}$ 


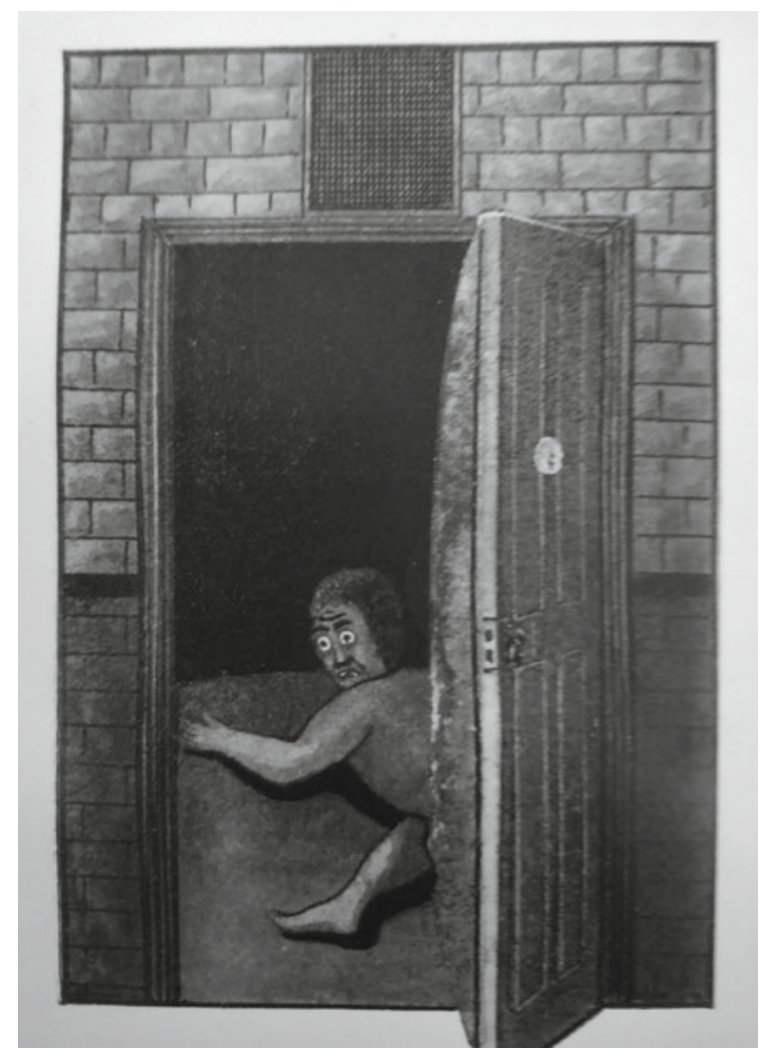

Fig. 3.5 James Scott's drawing of a seclusion room (James Scott, Sane in Asylum Walls [London: Fowler Wright, 1931], facing p. 102) (Copyright: owner sought but not found)

\section{Recovery, Convalescence and Discharge}

Despite inadequate and harsh treatment in asylums, a proportion of patients recovered sufficiently to be discharged. However, in 1916, Weatherly reminded his readers that "the recovery-rate of mental diseases is...no higher than it was in the 'seventies' of the last century."160 The annual recovery and discharge rate from lunacy institutions declined, from around 40 per cent of admissions between 1889 and 1905, to 32 per cent by 1914, and 27 per cent in 1918 (Table 3.2). In 1913, 
Table 3.2 Rates of recovery, 1878-1919, across all lunacy institutions in England and Wales

\begin{tabular}{lcccc}
\hline Years & $\begin{array}{c}\text { Men: \% of } \\
\text { annual } \\
\text { admissions }\end{array}$ & $\begin{array}{c}\text { Men: \% of total } \\
\text { resident }\end{array}$ & $\begin{array}{c}\text { Women: \% of } \\
\text { annual } \\
\text { admissions }\end{array}$ & $\begin{array}{c}\text { Women: \% of } \\
\text { total resident }\end{array}$ \\
\hline $1878-1882$ & 36.1 & 10.6 & 43.7 & 11.4 \\
$1883-1887$ & 35.6 & 9.7 & 44.5 & 10.6 \\
$1888-1897$ & 35.3 & 9.8 & 42.5 & 10.4 \\
$1898-1902$ & 34.7 & 9.2 & 40.4 & 9.3 \\
$1903-1907$ & 33.6 & 8.2 & 40.6 & 8.9 \\
$1908-1912$ & 30.8 & 6.6 & 37.7 & 7.6 \\
$1913-1917$ & 29.1 & 5.7 & 35.9 & 6.7 \\
1918 & 22.8 & 5.2 & 30.9 & 6.5 \\
1919 & 25.0 & 6.5 & 38.0 & 8.4 \\
\hline
\end{tabular}

Source Sixth Annual Report of the Board of Control, for the Year 1919 (London: HMSO, 1920) Appendix A, 22-23.

about 10,000 people were discharged, but some of them were classed as "relieved" (somewhat better) or "not improved", rather than "recovered". Recovery data are not straightforward, partly because the Board sometimes used the term synonymously with discharge. Data on recovery rates were also presented in two ways: as a proportion of the number of admissions in any one year and compared to the total asylum population (Table 3.2). ${ }^{161}$ The first gave a far more optimistic view than the second. These data are also difficult to interpret because numerous factors contributed to the changing discharge rates, such as admissions of more patients like Lily, with disturbed behaviour due to underlying physical illness, and bed shortages so that only the most unwell were admitted. Overcrowding and understaffing hindered staff-patient therapeutic relationships, reinforced custodial practices and minimised occupational and social treatments, all of which had the potential to affect recovery. Other less well-founded explanations for reduced recovery included that mental disorders were becoming more incurable and that clinicians were getting better at detecting insanity making them reluctant to discharge patients until all their symptoms had resolved. ${ }^{162}$ These explanations, convenient and credible to the leadership, exonerated the medical officers from failing to cure their patients while praising their expertise.

Although discharge became increasingly unlikely with longer duration of admission, ${ }^{163}$ some discharges occurred after many years, such 
as for Ida D (Fig. 3.6 $6^{164}$ ). Ida was a single 38 -year-old cork cutter who lived with her widowed mother in Whitechapel. ${ }^{165}$ She was admitted to Colney Hatch in 1914 with a one-month history of mental disturbance. She was discharged "not improved" in 1951, 37 years later. ${ }^{166}$ This preceded Ministry of Health policies on closing institutions and developing community care, suggesting that the discharge initiative came from the asylum itself or from friends or a charity outside the institution. Contrary to stereotypical assumptions, age was no bar to discharge, either for Ida after her long admission or for Albert A in 1914 (Fig. 3.6 ${ }^{167}$ ). Albert was a 73-year-old widowed, former horse cab driver from Stoke Newington then working as a messenger. ${ }^{168} \mathrm{He}$ was admitted to Colney Hatch with his "first attack" of insanity attributed to alcohol and arteriosclerosis. Four months later, shortly before war broke out, he was discharged to the care of his son. ${ }^{169}$ Despite overall poor discharge rates,


Fig. 3.6 Discharged contrary to expectations: Ida D and Albert A (Photographs of female patients 1908-1918 H12/CH/B/18/003 and male patients 1908$1920 \mathrm{Hl} 2 / \mathrm{CH} / \mathrm{B} / 19 / 003$ at Colney Hatch, LMA) 
the stories of Ida and Albert go some way to counteracting the impression of inevitable and permanent long-term confinement, even for patients considered to have an unfavourable outlook. ${ }^{170}$

As with other aspects of psychiatric care, asylum doctors aspired to the clinical methods of their colleagues who treated patients with physical illness or injury. In this case, a period of convalescence (from Latin, con valescere, to grow strong or well) was a frequent part of medical and surgical practice to enhance recovery. The concept of convalescence was widely understood including outside medicine, such as for national and economic health; Winston Churchill used it to describe the country's post-war recovery. ${ }^{171}$ Some asylums had convalescent wards in the main hospital, others had villas set aside in the grounds for that purpose. Unfortunately, detached villas were particularly vulnerable to being taken over for other purposes during the war, compounding the staffing and overcrowding challenges which impinged on therapeutic social interactions integral to the process of rehabilitation.

Convalescence, as many other aspects of asylum life, has been criticised by social scientists and historians. Stephen Soanes summarised views of Erving Goffman, Andrew Scull and others, that convalescence was part of a system of control, an extension of the ward system, a disciplinary mechanism, and that it "had a subordinate and perhaps deceptive place in the asylum, as classification that pointed to imminent release, but actually formed part of a primarily carceral institution." 172 This criticism ignored the imperative to discharge as many patients as possible in order to vacate beds to allow new admissions. It also failed to take into account the extraordinarily slow pace of recovery from mental breakdown, to rebuild self-confidence and self-esteem, deal with fear of relapse, and rebuild fractured social and employment relationships, hurdles recognised by some asylums which did provide convalescence. ${ }^{173}$

Alongside convalescence, the asylums had the option of granting a patient up to four weeks trial leave to help identify their needs prior to full discharge, aiming to prevent "early relapses - so vexatious and dispiriting to the authority concerned". ${ }^{174}$ Patients were described as being "on trial", a term with ambiguous judicial connotations. Hubert Bond, a senior member of the Board, advocated that asylums should follow the Lunacy Act, which permitted them to provide a monetary allowance for each patient during leave. ${ }^{175}$ This could relieve financial stress and might help create a successful outcome. Despite these ideals, asylums varied in their approach to trial leave, from none, ${ }^{176}$ to leave plus allowance. ${ }^{177}$ 
Some asylums would not provide the allowance, viewing it as unnecessary, or extravagant, even though many patients had no other financial support at that time. ${ }^{178}$ During the war, austerity meant that the London County Council did not enforce the recommendation, ${ }^{179}$ despite the risk of that impeding outcome.

To promote successful discharge, Bond also encouraged "after-care". The Mental After Care Association (MACA), was founded in 1879 by Henry Hawkins, chaplain at Colney Hatch. MACA mainly provided clothing, tools to help patients restart their trade, a place in a cottage home for convalescence, and assistance finding employment, ${ }^{180}$ tailoring its support to individual needs. ${ }^{181}$ It worked closely with local Guardians, who often had long-term knowledge about a family. ${ }^{182}$ MACA described itself as a "unique charity...doing work untouched by any other Association", ${ }^{183}$ but it was relatively small, its resources only stretching to about 600 discharges each year, mainly in the London area. ${ }^{184}$ Bond encouraged medical superintendents to inform MACA of impending discharges, with the patients' agreement, and MACA liaised constructively with medical superintendents, even after discharge. ${ }^{185}$

Bond wanted MACA to serve all patients who were likely to benefit from its support in the course of their discharge from a public asylum. ${ }^{186}$ However, there was diversity of opinion. Not all asylum committees agreed with Bond. One in Berkshire considered it inadvisable to have a dedicated "after-care committee" because

when patients are discharged...they do not in any way wish to be considered as in need of after-care or different from their fellows....in many cases it is obviously to their advantage, that their residence in a Mental Hospital should be forgotten. ${ }^{187}$

This opinion contradicted MACA's experience. For example, in the employment-seeking advertisements which it placed in newspapers on the patients' behalf, it often stated: "Has been mentally ill, now perfectly well and strong". 188 This honesty did not preclude former patients from obtaining work, although not all placements lasted, due to employer, employee, or wider social factors. ${ }^{189}$ Philanthropic donations also indicated public sympathy, rather than ostracism, towards people recovering from mental disorder, however, MACA's focus on London does not allow judgement about generosity or attitudes elsewhere. Despite donations, without statutory support, MACA lacked the means to satisfy demand for 
its services. In Bond's understanding, after-care helped prevent relapses, so was "economically worthy of generous support"190 and the Board requested funding for it in its proposals to the Reconstruction Committee in 1917. ${ }^{191}$ The evidence that after-care could benefit patients and that MACA received public support for its work, raises questions about the attitudes and understanding of those people running the asylums who opposed it.

MACA was necessarily selective about whom it supported, but many of those it helped remained well. ${ }^{192}$ Recipients were generally grateful, and some reimbursed the charity all that it had spent on them. ${ }^{193}$ Some case studies are preserved in the MACA archive, but it is unclear if they form a representative sample or a successful-outcome sample. Nevertheless, they provide insights into the diverse and personal support given, and a few are therefore worthy of mention here. One, Norman B, a 36-year-old electrical engineer who worked well in the asylum engineer's workshop during his admission, wanted to be a ship's engineer. With some financial support from MACA, and their letters to potential employers, he got work on board a ship, and went to Ceylon (Sri Lanka). ${ }^{194}$ Another, Annie Sh, was also helped by MACA. Her asylum admission was precipitated by her husband's marital infidelity. With MACA's help, Annie obtained a legal separation from him, custody of their three children and 15 shillings a week to support them. ${ }^{195}$

MACA also accepted a referral for George $\mathrm{C}$ who needed new clothes and sought work as a baker. It provided some clothing from its own store with the rest made-to-measure. It placed an advert in the Daily Chronicle: "Bakers.- Respectable young man, 20, seeks situation as assistant; experienced; good references." 196 George found a job quickly, but found the work too onerous, so left and enlisted with an infantry battalion in August 1914. Perhaps unsurprisingly, five months later he absconded, before embarking for France. ${ }^{197}$ George's account is a reminder of the situation of many men who enlisted shortly after discharged from asylums. Later in the war, some recruiting offices requested the names of recovering patients and expected them to register for military service before leaving the institution. ${ }^{198}$ Likewise, and contrary to Board recommendations, there was a drive to recruit young men registered as mental defectives. ${ }^{199}$ Recruitment officials ignored advice from the men's own doctors that they were unsuitable to serve, ${ }^{200}$ and a leader in the Times commented that physically fit men "were passed for service in the Army, when they were more fitted to be certified for asylums." 201 These criticisms point to 
Army recruitment officers paying little attention to existing understanding of mental disorders and the psychological resilience servicemen required. Such recruitment practices arguably contributed to the catastrophe of shell shock.

But, returning to George C, his story has a happy ending. He survived the war and appears to have had a satisfactory life thereafter. In 1936, 22 years after his discharge from the asylum, he sent Christmas greetings to his former MACA worker, Miss Vickers, indicating his gratitude to her. ${ }^{202}$

\section{CONCLUSIONS}

Treating patients with mental disorder, the raison d'être of the asylum, was fraught with tensions. Understanding about mental disorders-their causes, classification, course and treatment-was subject to a mismatch between scientific evidence, opinions and practices. Psychiatrists were presented with contradictory hypotheses and information, with the significance of each difficult to evaluate. Psychiatrists in England, as a group, were at odds as to what to believe. Although they did little research, they questioned what was presented to them, from the UK and abroad. Much discussion appeared in the JMS, which was published regularly through the war. Caution and healthy scepticism and acknowledgement of the risk of harm from adopting new practices too readily, created a safety mechanism when faced with radical options. However, these collective traits were also associated with inertia, and lack of innovation when the opportunities arose for making other, constructive changes.

Psychiatrists were trained, as were their medical contemporaries, to improve the lives of their patients, preferably to cure them. There was a sense of frustration that scientific advances in other medical disciplines surpassed those in their own. The overlap in symptoms between physical and mental disorders and the discovery of invisible causes of physical illnesses reinforced beliefs that mental and physical disorders had similar causes. This gave asylum doctors hope of scientific breakthroughs for the most severe forms of insanity. Lack of clinically useful discoveries, demoralising on the one hand, spurred some doctors on to persist with research, determined to achieve better for their patients. Various aspects of the lunacy system militated against this, such as geographical and intellectual isolation of asylums from teaching hospitals and universities, a lack of scientific expertise and heavy clinical responsibilities which gave 
no time for research. The paltry sum of money allocated for psychiatric research compared to that for physical illnesses was disproportionate to the challenge. It is arguable that heredity and degeneration hypotheses associated with negativity and inevitability about mental disorders may have deterred potential funders from sponsoring research. To achieve research-based improvements in clinical practice also required collaboration across professions and organisations-legal, medical, academic, asylum and governmental. That collaboration was absent before, during and after the war.

The Lunacy Act contributed to hindering asylum doctors from adopting patient-centred good medical practices expected of their counterparts in general hospitals. They were not allowed to offer out-patient treatment, to admit voluntary patients, or to decide who should be admitted to their beds, or at what stage of their illness. The Act did not serve the needs of many mentally unwell people. Convalescence, integral to treatment of physical illness and injury, was incorporated into some asylum regimes, but outside the asylum walls support was limited, mainly to that provided by MACA in the London area. MACA's work supported the notion of some public sympathy towards people seeking to resume their normal lives following an asylum admission.

Falling discharge rates (and high death rates; see Chapter 7) indicate declining standards in the asylums before the war. Pressures on the asylums during the war, particularly of overcrowding with a depleted staff, added to untherapeutic environments associated with more custodial care, some punitive practices, and a fall in therapeutic interventions. Overall, the impression given is of asylum practices pulled in all directions by scientific, legal, social, economic, military and other factors, sometimes floundering in uncertainty and at other times knowing what should be done but hampered by internal and external constraints. The voice of the patient and his family was missing. There is evidence that clinical practice was associated with a degree of self-justification by the medical and lay leadership, and that deception may have hidden harsh practices and affected statistics, possibly contributing to a more positive image of the asylums than they deserved. 


\section{Notes}

1. Colney Hatch $\mathrm{H} 12 / \mathrm{CH} / \mathrm{B} / 16 / 003$ Case notes of female patients who died 1918-1919 LMA.

2. Anon. The LCC Hospitals: A Retrospect (London: LCC, 1949), 46.

3. Committee on the Administration of Public Mental Hospitals (Chairman: Sir Cyril Cobb) (Cobb Inquiry), 16 March 1922 Charles McCarthy Q:811, MH 58/219 TNA.

4. John Keay, "Presidential Address on the War and the Burden of Insanity," Journal of Mental Science (JMS) 64 (1918): 325-44, 341.

5. Tom Williams, "The Management of Confusional States with Special Reference to Pathogenesis," JMS 63 (1917): 389-400.

6. WA Cramond, "Psychiatry and Old Age: The Psychiatric Hospital and the Aged Patient," Nursing Mirror, 17 March 1961, xi-xii.

7. Colney Hatch $\mathrm{H} 12 / \mathrm{CH} / \mathrm{B} / 18 / 004$ Photographs of female patients admitted and discharged 1918-1920 LMA; Annual Report: Barony Parochial Asylum at Woodilee, Dunbartonshire, 1901-1902, HB30/2/12A19 NHS Greater Glasgow Archives.

8. Claybury LCC/MIN/00948 Meeting, 3 January 1918, 286 LMA.

9. Colney Hatch $\mathrm{H} 12 / \mathrm{CH} / \mathrm{B} / 16 / 003$ Case notes of female patients who died 1918-1919 LMA.

10. German Berrios, "British Psychopathology Since the Early 20th Century," 232-44, in 150 Years of British Psychiatry 1841-1991, ed. German Berrios and Hugh Freeman (London: Gaskell, 1991), 232-33.

11. German Berrios, "Delirium and Confusion in the 19th Century: A Conceptual History," British Journal of Psychiatry 139 (1981): 439-49, 446; Edward Younger, Insanity in Everyday Practice (London: Baillière, Tindall and Cox, 1914), 36.

12. Berrios, "Delirium": 439.

13. Colney Hatch $\mathrm{H} 12 / \mathrm{CH} / \mathrm{B} / 22 / 015$ Autopsy book for female patients 1918-1919 LMA.

14. R Percy Smith, "Mental Disorders in Civilians Arising in Connexion with the War," Proceedings of the Royal Society of Medicine (Proc RSM) 10 (1917): Section of Psychiatry, 1-20, 11-12, 20.

15. JM Winter, "The Impact of the First World War on Civilian Health in Britain," Economic History Review 30 (1977): 487-507, 503; Reconstruction Committee, letters to BoC, 14 August 1916 and 2 January 1917 MH 51/687 TNA; Pat Thane, Divided Kingdom: A History of Britain, 1900 to the Present (Cambridge: Cambridge University Press, 2018), 56-57.

16. Edgar Jones, Robin Woolven, Bill Durodié, and Simon Wessely, “Civilian Morale During the Second World War: Responses to Air Raids ReExamined," Social History of Medicine 17 (2004): 463-79. 
17. Hazel Croft, "Rethinking Civilian Neuroses in the Second World War," 95-116, in Traumatic Memories of the Second World War and After, ed. Peter Leese and Jason Crouthamel (London: Palgrave Macmillan, 2016).

18. BoC, Patients Admission Registers: Rate aided admissions, 1914-1918. Forty-nine names collected at random from admission registers. $\mathrm{MH}$ 94/48-53 TNA.

19. Colney Hatch $\mathrm{H} 12 / \mathrm{CH} / \mathrm{B} / 16 / 002$ Case notes of female patients who died 1916-1917 LMA; Rate-aided admissions, to asylums, hospitals, licenced houses (excluding idiot institutions) $1915 \mathrm{MH}$ 94/50 TNA; Colney Hatch $\mathrm{H} 12 / \mathrm{CH} / \mathrm{B} / 18 / 003$ Photographs of female patients admitted and discharged 1908-1918 LMA.

20. Pamela Michael, Care and Treatment of the Mentally Ill in North Wales 1800-2000 (Cardiff: University of Wales Press, 2003), 119.

21. Harry Bernstein, The Invisible Wall (London: Hutchinson, 2007), 168.

22. Vera Brittain, Testament of Youth (1933; London: Virago Press, 1982).

23. Claybury, Female patient case notes 1917, Redbridge Heritage Centre.

24. England and Wales Register 1939, https://www.ancestry.co.uk/search/ collections/1939ukregister/.

25. Eunice Winters (ed.), The Collected Papers of Adolf Meyer, vol. 2. (Baltimore: John Hopkins, 1951), 250, quoted in Edward Shorter, A History of Psychiatry (New York: Wiley, 1997), 90.

26. Colney Hatch $\mathrm{H} 12 / \mathrm{CH} / \mathrm{B} / 18 / 004$ Photographs of female patients admitted and discharged 1918-1920 LMA.

27. Tracy Loughran, Shell-Shock and Medical Culture in First World War Britain (Cambridge: Cambridge University Press, 2017), 60.

28. Ernest Jones, in discussion on: Charles Mercier, "The Concept of Insanity," Proc RSM 7 (1914): Section of Psychiatry, 3-14, 13; Younger, Insanity, 4.

29. Lunacy Act 1890 section 341.

30. Mercier, “Concept of Insanity": 3-4.

31. John Turner, “The Classification of Insanity,” JMS 58 (1912): 9-25, 10.

32. Younger, Insanity, 5.

33. Peter Bartrip, "A Talent to Alienate: The 2nd Earl (Frank) Russell (1865-1931)," Russell: Journal of Bertrand Russell Studies 32 (2012): 101-26; Voluntary Mental Treatment Bill. Hansard HL Deb, 22 July 1914, vol. 17, cc.89-92.

34. For example, the form of a delusion, as a fixed, false belief, can point to specific types of disorder. Delusions can be experienced with variable content. One patient experienced delusions during the war about "abusive Marconigrams", being a spy and his thoughts being discovered by X-rays; Younger, Insanity, 48; Smith, "Mental Disorders in Civilians".

35. Jack Drescher, Carol North, and Alina Suris, "Out of DSM: Depathologizing Homosexuality,” Behavioral Sciences (Basel) 5 (2015): 565-75. 
36. Lunacy Law (Committal of Sane Persons). Hansard HC Deb, 28 February 1910, vol. 14, c.562.

37. Richard Rows, "Clinics and Centres for Teaching," JMS 60 (1914): 674-81.

38. David Healy, Margaret Harris, Fiona Farquhar, Stefanie Tschinkel, and Joanna Le Noury, “Historical Overview: Kraepelin's Impact on Psychiatry," European Archives of Psychiatry and Clinical Neuroscience 258 (Suppl. 2) (2008): 18-24.

39. Mercier, "Concept of Insanity": 14.

40. Havelock Ellis, “A Criticism of Kraepelin," JMS 60 (1914): 523-26.

41. James Anglin, "Presidential Address, Delivered at the Seventy-Fourth Annual Meeting of the American Medico-Psychological Association, Chicago, Ill., June 4th-7th, 1918," JMS 65 (1919): 1-16, 1.

42. William Ford Robertson, "Vaccine Treatment in Asylums," JMS 60 (1914): 17-30.

43. Bernard Hollander, The First Signs of Insanity: Their Prevention and Treatment (London: Stanley Paul and Co, 1912), 143; Charles Mercier, A Textbook of Insanity (London: George Allen and Unwin, 1914), 14.

44. Jennifer Wallis, Investigating the Body in the Victorian Asylum: Doctors, Patients, and Practices (London: Palgrave Macmillan, 2017), 1-6.

45. Robert Mccarrison, "The Ductless Glands," Lancet 28 March 1914, 931; Rupert Farrant, "The Causation and Cure of Certain Lunacies," Lancet 24 June 1916, 1260-61.

46. Ngram viewer, "Pull Yourself Together," https://books.google.com/ ngrams.

47. Montagu Lomax, The Experiences of an Asylum Doctor (London: Allen and Unwin, 1921), 88.

48. Commissioners in Lunacy, Tables xvii (male), xviii (female): causes of first admissions, excluding to idiot establishments, 1907-1911 MH 51/687 TNA.

49. E.g. Sebastian Barry, The Secret Scripture (London: Faber and Faber, 2008); Maggie O'Farrell, The Vanishing Act of Esme Lennox (London: Headline Review, 2006); Younger, Insanity, 105-8; David Jones, "Moral Insanity and Psychological Disorder: The Hybrid Roots of Psychiatry," History of Psychiatry 28 (2017): 263-79.

50. Mental Deficiency Act, 1913 section 2.

51. Lomax, Experiences, 55; Cobb Inquiry, 16 February 1922 Dr. Bond Q:99-102, MH 58/219 TNA.

52. Cobb Inquiry, 24 February 1922 Dr. Perceval Q:362; 16 February 1922 Dr. Bond Q:99-100, 109; MH 58/219 TNA.

53. Cobb Inquiry, 24 March 1922 Lionel Weatherly Q:1581, MH 58/219 TNA. 
54. Cobb Inquiry, 16 March 1922 Nurse Jane Dagg Q:952, 957, MH $58 / 219$ TNA.

55. Cobb Inquiry, 24 March 1922 Lionel Weatherly Q:1597; 16 March 1922 Herbert Ellis JP Q:902, MH 58/219 TNA.

56. Hugh Freeman, "Psychiatry in Britain c.1900," History of Psychiatry 21 (2010): 312-24, 316-17.

57. Since 1963, British Journal of Psychiatry.

58. Robertson, "Vaccine Treatment"; Harold Gettings, "Dysentery Past and Present," JMS 60 (1914): 39-56; DJ Jackson, "The Clinical Value and Significance of Leucocytosis in Mental Disease," JMS 60 (1914): 56-72; Patrick O'Doherty, "Some Features of the Recent Outbreak of Enteric Fever at Omagh District Asylum," JMS 60 (1914): 76-81.

59. H Wolseley-Lewis and RH Cole, "The Amendment of Lunacy Legislation," Lancet 26 January 1918, 163.

60. James Whitwell, "The Administration of Bromide," Lancet 5 January 1918, 35; EW Adams, "The Administration of Bromide," Lancet, 12 January 1918, 8; Maurice Craig, "The Administration of Bromide," Lancet 19 January 1918, 119.

61. Lionel Weatherly, "Sexual Perversion," Lancet 22 June 1918, 884-85; Brian Donkin, "Sexual Perversion," Lancet 13 July 1918, 56.

62. George Savage, "The Presidential Address, Delivered at the Opening Meeting of the Section of Psychiatry of the Royal Society of Medicine, on October 22nd, 1912," JMS 59 (1913): 14-27, 27.

63. Freeman, "Psychiatry in Britain": 321.

64. JL Wheatley, Town Clerk, Cardiff, letter to Commissioners in Lunacy: State aid for research into mental diseases and mental defect, 13 December $1912 \mathrm{MH} \mathrm{51/78} \mathrm{TNA.}$

65. BoC, Research Committee, minutes, 30 July 1914, 13 MH 51/82 TNA.

66. BoC W/FM, 2 December 1914, 268 MH 50/43 TNA; BoC correspondence with Dr. J Shaw Bolton, MS, Wakefield Asylum, 25 March, 27 March, 4 December 1914, MH 51/79 TNA.

67. Henry Harris, National Health Insurance in Great Britain, 1911 to 1921 (Washington, DC: Government Printing Office, 1923), 10; BoC, Research Committee, minutes, 30 July 1914, 5 MH 51/82 TNA.

68. Dean of Faculty of Medicine, University of Manchester, letter to BoC 4 April 1914 MH 51/80 TNA; Sidney Coupland, BoC, "Report on Replies to Circular Letter re: Scientific Research," 1914 MH 51/81 TNA.

69. First Annual Report of the Board of Control, for the Year 1914 (London: HMSO, 1916) (BoC AR 1914), Part 1, 61-62; Lewis Bruce, "The Complement-Deviation in Cases of Manic-Depressive Insanity," JMS 60 (1914): 177-84. 
70. Keay, "War and the Burden of Insanity": 341.

71. Oliver Sacks, Awakenings (New York: Summit Books, 1973).

72. Harold Pinter, A Kind of Alaska: A Play, in Other Places (London: Methuen, 1982).

73. NPAS Johnson, "The Overshadowed Killer: Influenza in Britain in 1918-19," 132-155, in The Spanish Influenza Epidemic of 1918-19, ed. Howard Phillips and David Killingray (London: Routledge, 2003), 139; The relationship was clarified in 1982: RT Ravenholt and William Foege, "1918 Influenza, Encephalitis Lethargica and Parkinsonism," Lancet 16 October 1982, 860-64.

74. BoC circular, Evidence of Syphilis. Replies from County and Borough Mental Hospitals, 2 August 1928 MH 51/539 TNA.

75. Keay, "War and the Burden of Insanity": 337.

76. Younger, Insanity, 56.

77. Younger, Insanity, 15.

78. M Fitzmaurice-Kelly, "Salvarsan in General Paralysis of the Insane and Tabes," JMS 59 (1913): 498-502.

79. George Schrøder and $\mathrm{Hj}$. Helweg, "Some Experiments on Treatment of Dementia Paralytica with Subdural Injections of Neosalvarsan," JMS 65 (1919): 24-36.

80. Younger, Insanity, 88-89.

81. Claybury LCC/MIN/00945 Meeting, 12 November 1914, 231; LCC LCC/MIN/00581 Meeting, 26 October 1915, 56 LMA.

82. Colney Hatch LCC/PH/MENT/04/016 Lists of patients admitted, died and recommended for discharge 1911-1917 LMA.

83. Colney Hatch: $\mathrm{H} 12 / \mathrm{CH} / \mathrm{B} / 17 / 002$ Case notes of male patients who died in 1917; H12/CH/B/23/013 Autopsy book for male patients 1916-1918 LMA.

84. Shorter, History of Psychiatry, 379fn9, citing Psychiatrisch-Neurologische Wochenschrift, 4 January 1919.

85. William Halsted, "The Results of Operations for the Cure of Cancer of the Breast Performed at the Johns Hopkins Hospital from June, 1889, to January, 1894," Annals of Surgery 20 (1894): 497-555; Stefano Zurrida, Fabio Bassi, Paolo Arnone, Stefano Martella, Andres Del Castillo, Rafael Ribeiro Martini, M. Eugenia Semenkiw, and Pietro Caldarella, "The Changing Face of Mastectomy (from Mutilation to Aid to Breast Reconstruction)," International Journal of Surgical Oncology (2011): 1-7, 2. Article ID: 980158, https://dx.doi.org/10.1155/ $2011 / 980158$.

86. Shorter, History of Psychiatry, 111-12.

87. Gerald Grob, "The Rise and Decline of Tonsillectomy in TwentiethCentury America," Journal of the History of Medicine and Allied Sciences 62 (2007): 383-421, 387. 
88. Thomas Bewley, Madness to Mental Illness: A History of the Royal College of Psychiatrists (London: RCPsych Publications, 2008), 47; Andrew Scull, "Focal Infection," 79-81, in A Century of Psychiatry, ed. Hugh Freeman (London: Mosby, 1999).

89. BoC W/FM, 16 September $1914 \mathrm{MH} \mathrm{50/43;} 31$ March 1915, 383 $\mathrm{MH} \mathrm{50/44} \mathrm{TNA.}$

90. Younger, Insanity, 46; William Stoddart, Mental Nursing (London: Scientific Press, 1916), 79.

91. Stoddart, Mental Nursing, 78-79.

92. BoC W/FM, 17 June 1914, 97 MH 50/43 TNA; BoC AR 1914, Part 1,30 .

93. H Dodwell, “'Status Lymphaticus,' the Growth of a Myth," BMJ 16 January 1954, 149-51.

94. Ann Dally, "Status Lymphaticus: Sudden Death in Children from 'Visitation of God' to Cot Death," Medical History 42 (1997): 70-85.

95. Loughran, Shell-Shock, 54.

96. Jack Pressman, Last Resort: Psychosurgery and the Limits of Medicine (Cambridge: Cambridge University Press, 1998), 19, 84.

97. Frederick Mott, "War Psycho-Neurosis," Lancet 2 February 1918, 16972; Hudson Bury, "Remarks on the Pathology of War Neuroses," Lancet 2 July 1918, 97-99.

98. Ministry of Pensions, letter to BoC, 25 July 1917 MH 51/694 TNA.

99. Daniel Pick, Faces of Degeneration: A European Disorder, c.1848-c.1918 (Cambridge: Cambridge University Press, 1989), 18-19.

100. George Rosen, Madness in Society: Chapters in the Historical Sociology of Mental Illness (Chicago: University of Chicago Press, 1980), 255.

101. Bénédict Morel, Traité des Dégénérescences Physiques, Intellectuelles et Morales de L'espèce Humaine et des Causes qui Produisent ces Variétés Maladives (London: H. Baillière, 1857).

102. Henry Maudsley, "Considerations with Regard to Hereditary Influence," JMS 8 (1863): 482-512 and 9 (1864): 506-30; Younger, Insanity, 53; Pick, Faces of Degeneration, 9, 13.

103. Benjamin Seebohm Rowntree, Poverty: A Study of Town Life (London: Macmillan, 1902), 304-5.

104. Mercier, Textbook of Insanity, 44.

105. William Bynum, "Alcoholism and Degeneration in 19th Century European Medicine and Psychiatry," British Journal of Addiction 79 (1984): 59-70, 59.

106. Census 1911, https://www.ancestry.co.uk/cs/uk1911census.

107. Colney Hatch LCC/PH/MENT/04/016 Lists of patients admitted, died and recommended for discharge 1911-1917 LMA; Census 1911, https://www.ancestry.co.uk/cs/uk1911census; London Church of England marriage banns, 1754-1932, https://www.ancestry.co.uk/ search/collections/lmamarriages/, 28 June 1914. 
108. Richard Walter, "What Became of the Degenerate? A Brief History of a Concept," Journal of the History of Medicine and Allied Sciences 11 (1956): 422-29, 427.

109. Robert Armstrong-Jones, "The Eighth Annual Report of the Board of Control for the Year 1921," Eugenics Review 15 (1923): 426-32.

110. Shorter, History of Psychiatry, 98.

111. Pick, Faces of Degeneration, 17.

112. BoC, Resolution from the Sevenoaks Board of Guardians: "Motion to be Proposed by Mrs Pearce-Clark” April 1918 MH 51/667 TNA.

113. BoC, W/FM, 31 January 1917, 39, discussion about letter from Sir George Savage, $\mathrm{MH} 50 / 45$; BoC response to Resolution from the Sevenoaks Board of Guardians: "Motion to be Proposed by Mrs Pearce-Clark" April 1918 MH 51/667 TNA.

114. British Psychological Society, timeline 1901-2009, https://www.bps. org.uk/sites/bps.org.uk/files/History\%20of\%20Psychology/Timeline\% 20of\%20the\%20BPS\%201901\%20to\%202009.pdf; London Psychoanalytical Society, founded by Ernest Jones, 1913; RD Hinshelwood, "Psychodynamic Psychiatry Before World War 1," 197-205, in 150 Years of British Psychiatry, ed. Berrios and Freeman, 202.

115. Bernard Hart, The Psychology of Insanity (Cambridge: University Press, 1912).

116. Lomax, Experiences, 83.

117. Hanwell H11/HLL/C/06/006 Male attendants' fine book 1914-1935 LMA; Lomax, Experiences, 83.

118. Ernest Jones, Papers on Psycho-Analysis (London: Bailliére, Tindall and Cox, 1913).

119. Yves Delage, "Psychoanalysis, a New Psychosis. Une Psychose Nouvelle: La Psychoanalyse. Mercure de France, September 1st, 1916," JMS 63 (1917): 61-76.

120. Charles Mercier, "Diet as a Factor in the Causation of Mental Disease," JMS 62 (1916): 505-29, 529.

121. William HR Rivers, "The Repression of War Experience," Lancet 2 February 1918, 173-77, 174-76.

122. Loughran, Shell-Shock, 158.

123. Dean Rapp, "The Early Discovery of Freud by the British General Educated Public, 1912-1919," Social History of Medicine 3 (1990): 217-43.

124. Hollander, First Signs, 5.

125. Hollander, First Signs, 5; Grafton Elliott Smith and Tom Pear, Shell Shock and Its Lessons (Manchester: University Press, 1917), 109.

126. Lomax, Experiences, 39.

127. Cobb Inquiry, 30 March 1922 Edward Mason Q:2056, MH 52/220 TNA. 
128. Cobb Inquiry, 16 March 1922 Charles McCarthy Q:836, MH 52/219 TNA.

129. William Bynum, "Rationales for Therapy in British Psychiatry: 17801835," Medical History 18 (1974): 317-34, 331-32.

130. Younger, Insanity, 37-39.

131. Younger, Insanity, 71.

132. Younger, Insanity, 40.

133. Maurice Craig and ED Macnamara, "Treatments of Mental Disorders," 484-97, in The Practitioner's Encyclopaedia of Medical Treatment, ed. W Langdon Brown and J Keogh Murphy (London: Oxford University Press, 1915), 489.

134. Claybury LCC/MIN/00946 Meeting, 8 July 1915, 168 LMA.

135. Shorter, History of Psychiatry, 196 and 379fnl 8 citing John Haslam, Observations on Madness and Melancholy (London: Callow, 1809).

136. 1 minim $=1 / 480$ fluid ounce $=60 \mathrm{~mm}^{3}=$ one drop of water; PP Laidlaw, "Purgatives and Cholagogues," 722-30, in Practitioner's Encyclopaedia of Medical Treatment, ed. Langdon Brown and Keogh Murphy, 726.

137. Lomax, Experiences, 100; Cobb Inquiry, 24 March 1922 Lionel Weatherly Q:1677-79, MH 52/219 TNA.

138. Ministry of Health, Report of the Committee on Administration of Public Mental Hospitals Cmd. 1730 (London: HMSO, 1922) Annotated draft 112, 114-17 MH 52/222 TNA.

139. Lomax, Experiences, 96.

140. Stoddart, Mental Nursing, 38-39.

141. Jane Hamlett and Lesley Hoskins, "Comfort in Small Things? Clothing, Control and Agency in County Lunatic Asylums in Nineteenth- and Early Twentieth-Century England," Journal of Victorian Culture 18 (2013): 93-114, 98.

142. Lunacy Act 1890 section 40.

143. BoC circular concerning record keeping: Form 9: seclusion and mechanical restraint. 6 May 1922, 607C MH 51/240 TNA.

144. Lomax, Experiences, 84.

145. Stoddart, Mental Nursing, 38-39.

146. Lomax, Experiences, 96-97.

147. BoC AR 1914, Part 2, Three Counties Asylum 16 June 1914, 196; Long Grove Asylum 11 December 1914, 278.

148. Cobb Inquiry, 24 March 1922 Lionel Weatherly Q:1684 MH 52/219 TNA.

149. Claybury LCC/MIN/00947 Meeting, 22 June 1916, 146-47 LMA.

150. Claybury LCC/MIN/00947 Meeting, 23 November 1916. Between pp. 273-74 LMA. 
151. Lionel Weatherly, A Plea for the Insane: The Case for Reform in the Care and Treatment of Mental Diseases (London: Grant Richards Ltd, 1918), 33.

152. Lionel Weatherly, “The Management of Lunacy Patients," Lancet 21 September 1918, 405-6.

153. Weatherly, Plea for the Insane, 33.

154. Lomax, Experiences, 47-48.

155. John Hopton, "Prestwich Hospital in the Twentieth Century: A Case Study of Slow and Uneven Progress in the Development of Psychiatric Care," History of Psychiatry 10 (1999): 349-69, 362.

156. Lomax, Experiences, 46.

157. Lomax, Experiences, 83.

158. D Davidson, Remembrances of a Religio-Maniac (Stratford-on-Avon, UK: Shakespeare Press, 1912), 50-51.

159. James Scott, Sane in Asylum Walls (London: Fowler Wright, 1931), 98, and picture facing p. 102.

160. Lionel Weatherly, "The Work of the Registered Hospitals for the Insane," Lancet 5 August 1916, 248.

161. Sixth Anmual Report of the Board of Control, for the Year 1919 (London: HMSO, 1920) Appendix A, 22-23.

162. Anon. "Asylum Reports: London County Council, 1914," JMS 62 (1916): 627-34, 632 .

163. BoC, Patients admission registers: Rate aided admissions, 1913-1918 MH 94/48-53 TNA.

164. Colney Hatch $\mathrm{H} 12 / \mathrm{CH} / \mathrm{B} / 18 / 003$ Photographs of female patients admitted and discharged 1908-1918 LMA.

165. Census 1911, https://www.ancestry.co.uk/cs/uk1911census.

166. BoC, Patients admission registers: Rate aided admissions, $1914 \mathrm{MH}$ 94/49 TNA.

167. Colney Hatch $\mathrm{H} 12 / \mathrm{CH} / \mathrm{B} / 19 / 003$ Photographs of male patients admitted and discharged 1908-1920 LMA.

168. Census 1911, https://www.ancestry.co.uk/cs/uk1911census.

169. Colney Hatch: $\mathrm{H} 12 / \mathrm{CH} / \mathrm{B} / 13 / 066$ Case book for male patients admitted 1912-1914; LCC/PH/MENT/04/016 Lists of patients admitted, died and recommended for discharge 1911-1917 LMA.

170. Peter Barham, Forgotten Lunatics of the Great War (New Haven and London: Yale University Press, 2004), 3.

171. Stephen Soanes, "Rest and Restitution: Convalescence and the Public Mental Hospital in England, 1919-39" (PhD thesis, University of Warwick, 2011), http://wrap.warwick.ac.uk/54604/1/WRAP_T HESIS_Soanes_2011.pdf, 6 .

172. Soanes, "Rest and Restitution": 21. 
173. Claybury: Female Patient Case Notes 1917, Louise F. Redbridge Heritage Centre.

174. C Hubert Bond, "After-Care in Cases of Mental Disorder, and the Desirability of Its More Extended Scope," JMS 59 (1913): 274-86.

175. Lunacy Act 1890 section 55 (1) (2).

176. BoC AR 1914, Part 2, Whittingham Asylum 28 February 1914, 252.

177. BoC AR 1914, Part 2, Claybury Asylum 27 June 1914, 269.

178. LCC LCC/MIN/00580, Meeting, 27 July 1915, 698 LMA; BoC AR 1914, Part 2, Derbyshire Asylum 8 July 1914, 216; Severalls Asylum 27 October 1914, 227.

179. LCC LCC/MIN/00580, Meeting, 27 July 1915, 698 LMA.

180. Anon. "The After-Care Association," JMS 60 (1914): 343-45.

181. Report of the Council, After Care Association (1914): 5, SA/MAC/B.1/27 WL.

182. MACA, Annie S, SA/MAC/G.3/14 WL.

183. Report of the Council, The Mental After Care Association for Poor Persons Convalescent or Recovered from Institutions for the Insane (1915): 3, $\mathrm{SA} / \mathrm{MAC} / \mathrm{B} .1 / 28 \mathrm{WL}$.

184. Report of the Council, The After Care Association for Poor Persons Discharged Recovered from Asylums for the Insane (1914): 4, $\mathrm{SA} / \mathrm{MAC} / \mathrm{B} . \overline{1 / 27 \mathrm{WL}}$.

185. MACA, Ernest C, SA/MAC/G.3/17 WL.

186. BoC AR 1914, Part 1, 10: Discharged recovered: 7487; Discharged not recovered: 2605.

187. Berkshire Mental Hospital, "Interim Report of the House Subcommittee on the Report of the Departmental Committee of Inquiry Dated 1922 and the Recommendations of the Board of Control Resulting from the Inquiry," 25 May $1923 \mathrm{MH}$ 51/686 TNA.

188. Daily Telegraph, 24 August 1916, SA/MAC/G.3/5 WL; Nursing Mirror, 26 November 1921, SA/MAC/G.3/8 WL.

189. MACA, Florence H, SA/MAC/G.3/5 WL.

190. Bond, "After-Care": 282-83.

191. BoC, letter to Reconstruction Committee, 9 February $1917 \mathrm{MH}$ 51/687 TNA.

192. Report of the Council, After Care Association (1914): 6, $\mathrm{SA} / \mathrm{MAC} / \mathrm{B} .1 / 27 \mathrm{WL}$.

193. Report of the Council, Mental After Care Association (1915): 5, $\mathrm{SA} / \mathrm{MAC} / \mathrm{B} .1 / 28 \mathrm{WL}$.

194. MACA, Norman B, SA/MAC/G.3/3 WL.

195. MACA, Annie Sh, SA/MAC/G.3/14 WL.

196. MACA, George C: Daily Chronicle, 16 June 1914, SA/MAC/G.3/4 WL. 
197. Police Gazette, 19 January 1915, https://www.ancestry.co.uk/search/ collections/ukpolicegazettes/.

198. Claybury LCC/MIN/00947 Meeting, 30 March 1916, 70, Ilford Tribunal letter to VC, 28 March 1916 LMA.

199. BoC W/FM request from Clerk of Smethwick Council, 11 October 1916, 289; 22 November 1916, 338 MH 50/44 TNA.

200. BoC, "Notes of Some Typical Mental Cases for Special Consideration," July 1917 MH 51/694 TNA.

201. Anon. "Lunacy During the War," Times, 6 September 1919.

202. MACA, George C, SA/MAC/G.3/4 WL.

Open Access This chapter is licensed under the terms of the Creative Commons Attribution 4.0 International License (http://creativecommons.org/licenses/ by $/ 4.0 /)$, which permits use, sharing, adaptation, distribution and reproduction in any medium or format, as long as you give appropriate credit to the original author(s) and the source, provide a link to the Creative Commons license and indicate if changes were made.

The images or other third party material in this chapter are included in the chapter's Creative Commons license, unless indicated otherwise in a credit line to the material. If material is not included in the chapter's Creative Commons license and your intended use is not permitted by statutory regulation or exceeds the permitted use, you will need to obtain permission directly from the copyright holder.



